\title{
Understanding of the Elderly Attached to the Family Health Strategy about the HIVIAIDS Infection

\begin{abstract}
Cláudia Jeane Lopes Pimenta1, Iluska Pinto da Costa ${ }^{2}$, Eliane de Sousa Leite ${ }^{3}$, Maria do Carmo Andrade Duarte de Fariass ${ }^{4}$, Thiago Lívio Barbosa ${ }^{1}$, Ewerton José de Souza Maciel1", Vanessa Rolim Barreto Cavalcante ${ }^{4}$, Janaíne Chiara Oliveira Moraes ${ }^{5}$, Cleane Rosa da Silva ${ }^{6}$, Rubens Félix de Lima1, Kátia Neyla de Freitas Macedo Costa7, Maria José Menezes Brito ${ }^{8}$, Mayara Muniz Dias Rodrigues ${ }^{7}$ Jesana Sá Damasceno
\end{abstract}

\section{Abstract}

Introduction: Populational aging is a phenomenon that causes changes in the whole world, highlighting the spread of HIVIAIDS on the elderly population, characterized as a public health problem.

Objective: Identifying the understanding of older people about prevention and transmission of HIVIAIDS and recognizing their opinion about the control of this disease.

Method: This is an exploratory-descriptive study of a qualitative approach, developed with 26 elderly enrolled in three Family Health Strategies on the city of Cajazeiras, Paraiba, Brazil. The data were collected in interview structured script, and the data were collected in an interview with structured script, and analyzed according to the Content Analysis Technique proposed by Bardin.

Results: From the participants of the research, 69.2\% were women, half aged between 60 to 69 years old. From the analysis of the discourses two thematic categories emerged: Understanding about HIV/ AIDS infection and responsibility for combating the disease.

Conclusion: There are gaps in relation to knowledge of older people about HIVIAIDS, what makes them vulnerable to acquiring the disease.
1 Bachelor of Nursing, Federal University of Campina Grande. Cajazeiras, Paraiba, Brazil.

2 Technical School of Health of Cajazeiras, Teacher's Training Center, Federal University of Campina Grande. Cajazeiras, Paraiba, Brazil.

3 Academic Unit of Nursing, Teacher's Training Center, Federal University of Campina Grande. Cajazeiras, Paraíba, Brazil.

4 Academic Unit of Life Sciences, Teacher's Training Center, Federal University of Campina Grande. Cajazeiras, Paraiba, Brazil.

5 Postgraduate Nursing Program, University of Pernambuco.

6 Nursing Student, Federal University of Paraiba. João Pessoa, Paraiba, Brazil.

7 Postgraduate Nursing Program, Federal University of Paraiba. João Pessoa, Paraiba, Brazil.

8 Postgraduate Program of the School of Nursing, Federal University of Minas Gerais. Belo Horizonte, Minas Gerais, Brazil.

\section{Contact information:}

Eliane de Sousa Leite.

Address: Academic Unit of Nursing, Teacher's Training Center, Federal University of Campina Grande. Cajazeiras, Paraíba, Brazil.

\section{” elianeleitesousa@yahoo.com.br}




\section{Introduction}

Infection with Human Immunodeficiency Virus (HIV) has shown the character of a multifaceted epidemic and of difficult control, focusing growing and silent in the population aged more than 50 years old and is one of the most worrying situations currently faced in health care [1].

Although HIV/AIDS was initially associated with homosexuality and sexual practices of young adults, in recent years there has been a considerable increase in the number of elderly affected by the disease. Epidemiological data show that, in Brazil, from 1980 to June 2009 there were diagnosed 13.665 cases of HIV/AIDS in people aged 60 or over, and 8.959 in men [2]. However, between 2010-2013 there were recorded 5.849 cases, over 3.485 in the male population, in three years the number of cases increased by almost half, compared to the number of cases in three decades. [3]

Studies $[4,5]$ show that the non-use of condoms, the biggest demand for prostitution services, the shortage of campaigns aimed at this audience, openness to the experience of sexuality and the demystification of sex in old age, using more frequent illicit drugs by these individuals, associated with the design of an asexual old, from society in general and yet, by health professionals themselves, are relevant factors that increase the susceptibility of the elderly to HIVIAIDS and several other Sexually Transmitted Infections (STIS), contributing, moreover, to the development of biopsychosocial problems.

Still through this perspective of vulnerability to HIV/ AIDS, some authors highlight the fragile knowledge of the aging population about the subject [5]. In a study [6] conducted among the elderly and young adult men, it was found that the understanding of the disease is associated inversely to the progress of age, being lower among the elderly when compared to younger subjects. This result awakes to the fact that the limited knowledge of the elderly about HIVIAIDS influences for the increased risk of contracting the virus, making it difficult to incorporate healthy behaviors.

The lack of information about the subject for the elderly set up extremely relevant in view of knowledge present themselves as key to reducing prejudice against HIV carriers. This gap contributes to the lack of investments in control measures and the implementation of preventive measures [5].

Thus, the spread of HIVIAIDS in older people, in Brazil, is a public health problem that requires managers and professionals who provide care to this population policy-making and more effective strategies. In care interface, prevention of STIs/HIV/ AIDS, priority is given to primary care, represented especially by the Family Health Strategy (FHS), which operates with a high population coverage, ease of access and comprehensive care to individuals in the family, seeking to solve the major health problems, based on the premise of health education as a fundamental principle for the decline of up picture of AIDS in Brazil [7].

Thus, the present study aims to identifying the understanding of the elderly about the prevention and transmission by HIVIAIDS, and recognizing their opinion about the control of this disease.

\section{Method}

This is a field of study, exploratory and descriptive, of a qualitative approach, carried out in three FHS in the city of Cajazeiras/PB, between June and July 2014. The sample consisted of all the elderly enrolled in Monitoring System of Hypertensive and Diabets (HIPERDIA) and the selection of participants was completed by simple random sampling, by drawing lots, and totaling 26 individuals.

Inclusion criteria were: being 60 years old or over, be ascribed to the selected FHS and registered in HIPERDIA program. Choosing this inclusion criterion was because, in most cases, these individuals receive guidance aimed to chronic diseases that present with their sexuality overlooked by health professio- 
nals, becoming thus a population vulnerable to STIs. The elderly with oral communication and cognitive deficit were excluded; the latter measured by the Mini Mental State Examination [8].

Data collection was held at the home of the elderly, through interviews with previously prepared script, containing sociodemographic data and the following questions: Is AIDS a serious disease? How is AIDS transmitted? How to prevent AIDS? Whose responsibility is it to fight AIDS?

The interviews were transcribed precise, and the data analyzed according to the Content Analysis Technique proposed by Bardin [9]. Later, it was used to build a system of categories, seeking to identify issues and relevant standards. In order to enable a better understanding of the organization, the content of the speeches was arranged in frames, where each category formed is divided into recording units, represented by their respective units' contexts. The speeches were identified by the letter "E" followed by the ordinal number corresponding to the interview order (E1, E2 ...) in order to preserve the anonymity of participants.

The research project was approved by the Ethics in Research Committee of the University Hospital Alcides Carneiro/Federal University of Campina Grande in CAAE No. 12154013.0.0000.5182 and Opinion 321609 number.

\section{Results}

\section{Characterization of the sample}

The study included 26 elderly, of which $69.2 \%$ were female. The predominant age group ranged from individuals between 60-69 years old (50\%); half of the elderly was married, had low literacy rate as $34.6 \%$ had less than eight years of education and $27 \%$ were illiterate.

With regard to individual income, $73.1 \%$ of the elderly were retired and received one (1) minimum wage, and $7.7 \%$ did not have retirement or employment, revealing the dependence of these indivi- duals for the provision of sustenance. On the family arrangement, $73.1 \%$ of the elderly referred reside with one to three people, and $76.9 \%$ had up to four children.

\section{Speeches of the elderly: thematic categories}

Category I - Understanding about the infection by HIVIAIDS

The Table 1 presents the analysis of category I and its respective subcategories derived: Gravity, Transmission and Methods of Prevention.

Table 1. Understanding of HIV/AIDS infection according to the speech of the elderly attached to FHS, Cajazeiras, PB. $(n=26)$.

\begin{tabular}{|c|c|c|c|}
\hline Subcategory & $\begin{array}{l}\text { Registration } \\
\text { Units }\end{array}$ & Context Units & $n *$ \\
\hline \multirow{3}{*}{ Gravity } & Very Serious & $\begin{array}{l}\text { It is one of the most } \\
\text { serious diseases that } \\
\text { exists today. (E8) }\end{array}$ & 22 \\
\hline & Not Serious & $\begin{array}{l}{[\ldots] \text { it's not so serious. }} \\
\text { (E17) }\end{array}$ & 2 \\
\hline & $\begin{array}{l}\text { Don't know } \\
\text { inform }\end{array}$ & I've never heard. (E7) & 2 \\
\hline \multirow{4}{*}{ Transmission } & Body Fluids & $\begin{array}{l}\text { By sex, by saliva, blood } \\
\text { donation and blood } \\
\text { transfusion [...]. (E1) }\end{array}$ & 7 \\
\hline & $\begin{array}{l}\text { Don't know } \\
\text { inform }\end{array}$ & I don't know. (E13) & 7 \\
\hline & $\begin{array}{l}\text { Myths and } \\
\text { Beliefs }\end{array}$ & $\begin{array}{l}\text { AIDS handle anyone } \\
\text { who has in her living } \\
\text { hand grip, get in right } \\
\text { kiss? (E20) }\end{array}$ & 9 \\
\hline & $\begin{array}{l}\text { Sharps and } \\
\text { Contaminated } \\
\text { Objects }\end{array}$ & $\begin{array}{l}\text { Takes from the syringe, } \\
\text { needles contaminated, } \\
\text { even dental material } \\
\text { can happen right? } \\
\text { (E22) }\end{array}$ & 3 \\
\hline \multirow{3}{*}{$\begin{array}{l}\text { Prevention } \\
\text { Methods }\end{array}$} & $\begin{array}{l}\text { Preservative } \\
\text { Use }\end{array}$ & $\begin{array}{l}\text { You should avoid } \\
\text { having sex without a } \\
\text { condom [...]. (E8) }\end{array}$ & 12 \\
\hline & $\begin{array}{l}\text { Amount of } \\
\text { Partners }\end{array}$ & $\begin{array}{l}\text { (...) it's only to stay } \\
\text { with one partner only. } \\
\text { (E15) }\end{array}$ & 9 \\
\hline & $\begin{array}{l}\text { Don't know } \\
\text { inform }\end{array}$ & $\begin{array}{l}\text { (...) I don't know how } \\
\text { you do not get. (E7) }\end{array}$ & 5 \\
\hline \multicolumn{2}{|c|}{ n: amount of speeches } & \multicolumn{2}{|c|}{$\begin{array}{r}\text { Source: A field research. } \\
\text { Cajazeiras, } 2014\end{array}$} \\
\hline
\end{tabular}




\section{Category II - Responsibility for combating the disease} About the proposition of category II 'Responsibility for combating the disease' emerged three subcategories, "Individual", "Public" and "Without knowledge", as can be seen in Table 2 .

Table 2. Responsibility for combating the disease, according to the speech of the elderly attached to FHS, Cajazeiras, Paraíba. $(n=26)$.

\begin{tabular}{|c|c|c|c|}
\hline Subcategory & $\begin{array}{l}\text { Registration } \\
\text { Units }\end{array}$ & Context Units & $n$ \\
\hline Individual & Personal & $\begin{array}{l}\text { The first responsibility } \\
\text { must be individually, } \\
\text { each person has to } \\
\text { have his care [...]. (E26) }\end{array}$ & 5 \\
\hline \multirow[t]{2}{*}{ Collective } & Society & $\begin{array}{l}\text { Everyone has to take } \\
\text { responsibility because } \\
\text { health is good. It's } \\
\text { great, you need to be } \\
\text { very careful, careful, } \\
\text { careful even. Great } \\
\text { care is. (E20) }\end{array}$ & 13 \\
\hline & $\begin{array}{l}\text { Health } \\
\text { Professionals }\end{array}$ & $\begin{array}{l}\text { We from health area } \\
\text { have more than the } \\
\text { other, there's always } \\
\text { more. (E11) }\end{array}$ & 2 \\
\hline $\begin{array}{l}\text { Without } \\
\text { knowledge }\end{array}$ & $\begin{array}{l}\text { Don't know } \\
\text { inform }\end{array}$ & $\begin{array}{l}\text { I don't know, I can't } \\
\text { explain exactly. (E13) }\end{array}$ & 6 \\
\hline
\end{tabular}

Source: A field research. Cajazeiras, 2014.

\section{Discussion}

According to data, in the subcategory "Gravity," 22 elderly reported that HIVIAIDS appear as a serious nature of disease. In contrast, four subjects had erroneous or insufficient knowledge about the disease, evidenced by the appearance of the recording units "No Record" and "Do not know the answer" (Table 1).

Knowledge of HIVIAIDS for the elderly has become indispensable today, given that from the understanding of issues related to infection, efficient and effective action can be developed, which will provide a protective effect. In addition, greater knowledge about HIVIAIDS can promote a different view on the dimensions surrounding the susceptibility of the elderly and may thus generate the creation of strategic actions for this public [5].

In order to remedy this problem, the installation of the HIVIAIDS epidemic in Brazil, there was the urgent need to spread information about the disease to the greatest possible number of individuals, the implementation of health and education policies in order to awaken them to the severity of the disease and its transmission and prevention [10]. However, it is clear that the spread of content on HIVIAIDS is taking place in an incomplete or ineffective way, not reaching properly, all population strata.

About the understanding of the elderly as the mode of transmission of the disease, stands out the little knowledge of the old, in which seven people reported not having knowledge about transmission of the virus and nine other associated it with myths and beliefs, as transmission by handshake (Table 1).

This coincides with data from a study [5] where it was observed that a large number of seniors had erroneous information and/or surrounded by myths and beliefs about the transmission of HIV/ AIDS, such as sharing soap, towels and toilet seats $(62.1 \%)$, mosquito bite $(79.9 \%)$, contact with cutlery, plates and glasses (62.3\%) and contaminated food (55.6\%).

In contemporary society, to be a person living with HIVIAIDS (PLWHA) still involves myths and prejudices, which condition to a life surrounded by stigma and social exclusion, for the most part, stressful and difficult fact. To minimize this situation, it is essential to revisit the way in which information is transmitted in order to correct the misconceptions about HIVIAIDS and its modes of transmission [1113].

Regarding the "Prevention Methods", there were identified three reporting units: Condom Use, Partner Amount and Don't know inform. With regard to condom use, most elderly people found this to be the best prevention for the disease. A study [14] that aimed to evaluate the knowledge of seniors on preventive actions for STIs in primary care showed that $90.1 \%$ of respondents believed that the use 
of condoms is the safest method to prevent contamination by the virus. However, the same study found that, when asked about sexual behavior, older people reported not having used a condom in some sex in the past.

These findings awaken to the importance of investigating the actual condom use by the elderly, as there is still resistance, especially by men who are afraid of losing an erection or the belief that such care must be taken in relations only with sex professionals [4-5]. Concerning women, motivated by a sense of confidence and stability experienced in marriage and not to worry about contraception, they feel no need to require the use of the method by partner $[4,15]$.

Once, despite the importance of condoms for prevention of HIVIAIDS emphasized, should also pay attention to other forms of transmission that show upside, with risky behavior among the elderly. A study [5] carried out with 224 elderly aimed to identify the level of knowledge about HIVIAIDS, found that $17.4 \%$ were injecting drug use, a factor that enhances the susceptibility to acquiring diseases, especially HIV virus.

In the unit "Partner quantity" nine seniors cited in order to prevent the sexual practice with a stable partner. A survey [16] developed with 384 users of a Testing Center and Monitoring evaluated the exposure to risk of infection with STI/HIVIAIDS and found that individuals who had a higher number of sexual partners were more likely to acquire infection.

However, despite the amount of partners directly influence the risk and vulnerability to HIVIAIDS, it is noted that the fact that the subject who has a stable relationship does not grant immunity to the virus, since the transmission can occur even in the singularity of a sexual relationship [17].

Also in Class I analysis, subcategory "Gravity", the emergence of unity "Don't know inform" (Table 1) confirms the existence of elderly without information on ways to prevent HIV/AIDS, which provides an increase in vulnerability of these individuals as it is needed adequate knowledge of prophylactic methods in order to develop an effective prevention approach against [5] the disease.

The results obtained with the category II demonstrate that, in the subcategory "Individual" registration unit "Personal" five elderly attributed to each of us the responsibility for the control of HIV infection (Table 2). In this case, the elderly understood that individual care is essential for disease prevention, with each one tasked to ensure their health.

From this perspective, it is necessary to develop in the elderly, personal skills through the empowerment and health education, so that it has the power to decide about their attitudes, behavior and care practices, reducing alienation and ignorance, in order to promoting health and minimizing the morbidity and mortality indicators of STIs and HIVIAIDS [14].

In the subcategory "Public", the registration units generated by the speeches of the participants highlighted the idea of two strands of thought, the role of society and health professionals. With regard to society, most elderly ( $n=13$ ) believed in the responsibility that all citizens have for HIVIAIDS is fought. The term care was reported in the statements, which implies providing assistance aimed at health and prevention of the beginning of infection, raising the state's duty to this condition.

Recent studies [18-19] reveal that although in Brazil there are some policies and programs, still lacks resources to the prevention of STIS/HIVIAIDS. Added to this, the failure in health care of the elderly, for care tends to just glimpse the demand, with complaints established, the absence of health promotion activities aimed at sexuality.

In this way, it remains fragile sense of responsibility of society to the control of HIVIAIDS. The commitment of civil society and a link between the state and the population through participation in representative areas is essential: councils, forums and working groups, seeking the organization and redefinition of its front fights the complexity of the current epidemic [19-20]. 
Relevant to the unit "Health Professionals", only two elderly attributed to health professionals the responsibility for the adoption of strategies for addressing HIV/AIDS. This suggests that older people are uninformed about the role of these actors in the disease process and its relevance in promoting diseases prevention actions.

Thus, health professionals have a fundamental role in combating HIVIAIDS, there is seen to be the main link in the control of disease transmission chain, providing the dissemination of relevant information about the subject, and demystifying beliefs. Thus, it favors the quality of life [21]. In turn, the resulting guidelines for health professionals can solve part of the conflicts related to STIS, the approach and education regarding sexuality on the population aged 60 years or older [17-18]. Often, the health professional has difficulties in addressing the elderly as regards their sexuality and facets that permeate sexually transmitted diseases, especially HIVIAIDS, which sometimes separates them from their social place surveillance health, hindering the development of effective and satisfactory actions.

The subcategory "Without knowledge" confirms that there is a dismissal of the elderly about the basic facts about HIVIAIDS. This result was corroborated by a study [14] conducted with 94 elderly, where only $24.5 \%$ reported having received counseling about sexually transmitted diseases during nursing visits, showing that users require assistance that emphasizes sexuality in aging.

So, in the face of high rates affected by HIV/ AIDS around the world, especially in the elderly population, the knowledge about the disease and about the means of transmission are essential for decision-making and the development of actions that seek to reduce the aspects of vulnerability, especially as regards the management of the care and completeness of the actions in that target audience [22].

\section{Conclusion}

The elderly had some understanding about HIV/ AIDS. However, most of the information was erroneous or insufficient for the development of safer sex practices, conditions which favor the increased susceptibility to disease.

This situation is aggravating, because they are elderly ascribed to the Family Health Strategy, assisted by a multidisciplinary team. In this sense, the personal views of professionals about HIVIAIDS establish direct influence on care management, becoming relevant constant reflection on the teacher's role, so as to trigger initiatives that generate clarifications and changes in the behavior of the elderly, directed to involvement with HIVIAIDS.

\section{References}

1. Rodrigues DAL, Praça NS. Mulheres com idade igual ou superior a 50 anos: ações preventivas da infecção pelo HIV. Rev. Gaúcha Enferm. [Internet], Porto Alegre, 2010 Jun; 31(2): 321-7. doi: http://dx.doi.org/10.1590/S1983-14472010000200017

2. Maschio MBM, Balbino AP, De Souza PFR, Kalinke LP. Sexualidade na terceira idade: medidas de prevenção para doenças sexualmente transmissíveis e AIDS. Rev. Gaúcha Enferm. [Internet], Porto Alegre, 2011 Sept; 32(3): 583-9. doi: http://dx.doi.org/10.1590/\$1983-14472011000300021

3. Departamento de Informática do Sistema Único de Saúde (DATASUS). Doenças de Notificação. On line [Internet]. Available from: http://www2.datasus.gov.br/DATASUS/index. php?area $=0203$

4. Santos AFM, Assis M. Vulnerabilidade das idosas ao HIVIAIDS: despertar das políticas públicas e profissionais de saúde no contexto da atenção integral: revisão de literatura. Rev. Bras. Geriatr. Gerontol. [Internet]. 2011 Jan/Mar; 14(1): 147-57. doi: http://dx.doi.org/10.1590/S1809-98232011000100015

5. Pereira GS, Borges $\mathrm{Cl}$. Conhecimento sobre HIVIAIDS de participantes de um grupo de idosos, em AnápolisGoiás. Rev. Esc. Anna Nery [Internet], Rio de Janeiro, 2010 Oct/Dec; 14(4): 720-5. doi: http://dx.doi.org/10.1590/S141481452010000400010

6. Melo HMA, Leal MCC, Marques APO, Marino JG. O conhecimento sobre Aids de homens idosos e adultos jovens: um estudo sobre a percepção desta doença. Ciênc. Saúde Coletiva [Internet], Rio de Janeiro, 2012 Jan; 17(1): 43-53. doi: http://dx.doi.org/10.1590/S1413-81232012000100007 
7. Fernandes $L C L$, Bertoldi $A D$, Barros AJD. Utilização dos serviços de saúde pela população coberta pela Estratégia de Saúde da Família. Rev. Saúde Pública [Internet], São Paulo, 2009 Aug; 43(4): 595-603. doi: http://dx.doi.org/10.1590/S0034$\underline{89102009005000040}$

8. Folstein MF, Folstein SE, Mchugh PR. Mini-Mental state: a practical method for grading the cognitive state for the clinician. J. Psychiatr. Res. [Internet], 1975; 12(3): 189-98. doi: http:// dx.doi.org/10.1016/0022-3956(75)90026-6.

9. Bardin L. Análise de conteúdo. 3. reimp., 1. ed. São Paulo: Edições 70; 2011.

10. Gonçalves TR, Carvalho FT, Faria ER, Goldim JR, Piccinini CA. Vida reprodutiva de pessoas vivendo com HIVIAIDS: Revisado a literatura. Psicol. Soc. [Internet], Florianópolis, 2009 May/Aug; 21(2): 223-32. doi: http://dx.doi.org/10.1590/S010271822009000200009

11. Marques Junior JS, Gomes R, Nascimento EF. Masculinidade hegemônica, vulnerabilidade e prevenção ao HIVIAIDS. Ciênc. Saúde Coletiva [Internet], Rio de Janeiro, 2012 Jan/Feb; 17(2): 51120. doi: http://dx.doi.org/10.1590/S1413-81232012000200024

12. Webel AR, Longenecker CT, Gripshover B, Hanson JE, Schmotzer BJ, Salata RA. Age, stress, and isolation in older adults living with HIV. AIDS Care [Internet]. 2014 Oct; 26(5): 523-31. doi: 10.1080/09540121.2013.845288

13. Rezende ELLF, Vasconcelos AMN, Pereira MG. Cause of death among people living with HIV/AIDS in Brazil. Brazilian J. Infect. Dis. [Internet], Salvador, 2010 Nov/Dec; 14(6): 558-63. doi: http://dx.doi.org/10.1590/S1413-86702010000600003

14. Cezar AK, Aires M, Paz AA. Prevenção de doenças sexualmente transmissíveis na visão de idosos de uma Estratégia da Saúde da Família. Rev. Bras. Enferm. [Internet], Brasília, 2012 Sept/Oct; 65(5): 745-50. doi: http://dx.doi.org/10.1590/S0034$\underline{71672012000500005}$

15. Miranda J, Côte J, Godin G, Blais M, Otis J, Guéhéneuc YG et al. An Internet-Based Intervention (Condom-Him) to Increase Condom Use Among HIV-Positive Men Who Have Sex With Men: Protocol for a Randomized Controlled Trial. JMIR Res. Protoc . [Internet], 2013; 2(2): e39. doi: 10.2196/resprot.2723

16. Monteiro SS, Brandão $E$, Vargas E, Mora C, Soares $P$, Daltro E. Discursos sobre sexualidade em um Centro de Testagem, e Aconselhamento (CTA): diálogos possíveis entre profissionais e usuários. Ciênc. Saúde Coletiva [Internet], Rio de Janeiro, 2014 Jan; 19(1): 137-46. doi: http://dx.doi.org/10.1590/1413$\underline{81232014191.1906}$

17. Rebello LEFS, Gomes R. Qual é a sua atitude? Narrativas de homens jovens universitários sobre os cuidados preventivos com a AIDS. Saúde Soc. [Internet], São Paulo, 2012; 21(4): 916-27. doi: http://dx.doi.org/10.1590/S0104-12902012000400011

18. Araújo CLO, Monteiro ACS. Qual a perspectiva da pessoa idosa em relação ao HIVIAIDS? Rev. Tem. Kairós Gerontol. [Internet], São Paulo, 2011 Dec; 14(5): 237-50. Available from: http://revistas.pucsp.br/index.php/kairos/article/view/9914/7368
19. Pereira AJ, Nichiata LYI. A sociedade civil contra a Aids: demandas coletivas e políticas públicas. Ciênc. Saúde Coletiva [Internet], Rio de Janeiro, 2011 July; 16(7): 3249-57. doi: http://dx.doi.org/10.1590/S1413-81232011000800024

20. Brooks JT, Buchacz K, Gebo KA, Mermin J. HIV Infection and Older Americans: The Public Health Perspective. American J. Public. Health [Internet], 2012 Aug; 102(8): 1516-26. doi: 10.2105/AJPH.2012.300844

21. Silva NEK, Ayres JRCM. Estratégias para comunicação de diagnóstico de HIV a parceiros sexuais e práticas de saúde. Cad. Saúde Pública [Internet], Rio de Janeiro, 2009 Aug; 25(8):1797-1806. doi: http://dx.doi.org/10.1590/S0102$\underline{311 \times 2009000800016}$

22. Borges MJL, Sampaio AS, Gurgel IGD. Trabalho em equipe e interdisciplinaridade: desafios para a efetivação da integralidade na assistência ambulatorial às pessoas vivendo com VIVIAIDS em Pernambuco. Ciênc. Saúde Coletiva [Internet], Rio de Janeiro, 2012 Jan; 17(1): 147-56. doi: http://dx.doi.org/10.1590/ $\underline{\mathrm{S} 1413-81232012000100017}$

\section{Comment on this article:}

\section{f(B) in $8+S$}

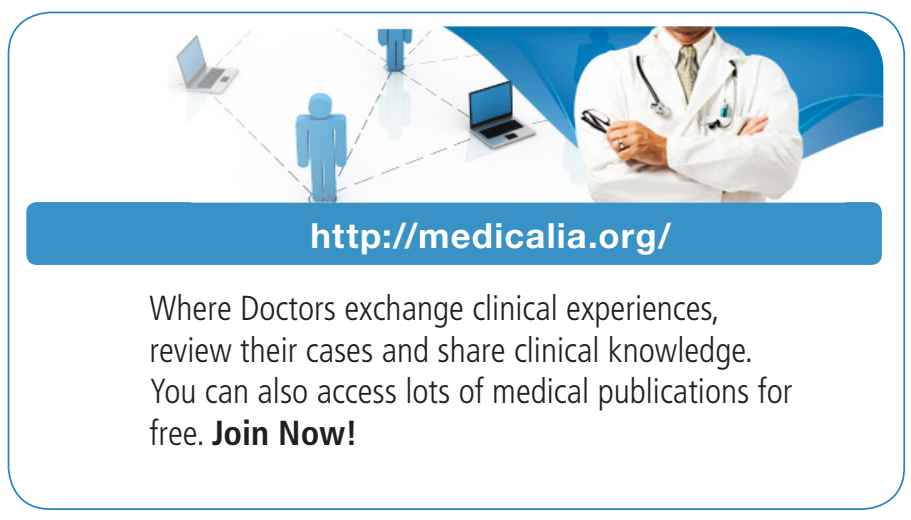

Publish with iMedPub

http://www.imed.pub

International Archives of Medicine is an open access journal publishing articles encompassing all aspects of medical science and clinical practice. IAM is considered a megajournal with independent sections on all areas of medicine. IAM is a really international journal with authors and board members from all around the world. The journal is widely indexed and classified Q1 in category Medicine. 